\title{
Translating Fictions: The Messenger Was a Medium
}

Lazer Lederhendler, Translator

The American translator Eliot Weinberger has remarked that "one can never mention the word "translation" without some wit bringing up - as though for the first time-that tedious Italian pun traduttore traditore" (5). While the exact origins of this famous-most translators would say infamous-Italian aphorism are open to dispute, there is no denying that traduttore traditore continues to serve as an axiom for today's prevailing assumptions about translation. The durability of this epigram is due at bottom to the potent etymological binding of its two terms through the proximity of their Latin roots: tradutorre from traducere-to lead across, to transfer-and traditore from tradere-to hand over, to deliver. (Tradere is also the forebear of "tradition," a genealogical correlation whose significance warrants further consideration.) Yet the aphorism's importance is more than philological and its implications go well beyond the time-worn piece of wisdom whereby the translated text is necessarily betrayed since something is always supposed to get "lost in translation." Significantly, it is the living (or once living) traduttore, the historically embodied agent of specific translations and not some abstract traduzione, that is explicitly denounced as a traitor-traditore.

Weinberger dismantles the "translator = traitor" equation by demonstrating that the "Utopian dream of exact equivalences" upheld largely by "members of foreign language departments" - whom he portrays as the shock troops of the "translation police" (6) - is a specious standard for measuring a translation's worth. He argues that a translation is essentially a reading, and no reading, whether within or across languages, can or should be identical to the original text or to any other reading of that text. It is probably no accident that this approach should be consistent with the one articulated by Octavio Paz, whose poetry has been made available to English readers thanks mainly to Eliot Weinberger's translations. Paz writes, "No text can be completely original because language itself, in its very essence, is already a translation-first from the non-verbal world, and then, because each sign and each phrase is a translation of another sign, another phrase" (154). Thus, "...reading is translation 
within the same language" (159). In sum, both Paz and Weinberger refute the charge of treason brought against the translator on the grounds that translation, and so by extension the translator, is a medium and as such must unavoidably transform the mediated work if it is to come alive in another language. And without the translator's mediation, Weinberger furthermore concludes, literature cannot live.

Adopting a somewhat different approach, the structuralist linguist Roman Jakobson, in his essay "On Linguistic Aspects of Translation," interrogates the traduttore traditore formula in specifically socio-linguistic terms: "[A] cognitive attitude would compel us to change this aphorism into a more explicit statement and to answer the questions: translator of what messages? betrayer of what values?" (435) For Jakobson, then, the two-faced nature of the translator-at once messenger and medium/betrayer - is a given. And the way those two faces are framed can justifiably be viewed in terms of the historical, cultural, ethical-in a word, political-functions of translation.

Thus, by virtue of the intrinsic operations of her work, the translator is at least to some degree involved in an intrigue where version must perforce engender a subversion of the original. In the early history of translation this drama of version and subversion emerges most famously in the activity of Saint Jerome, patron of translators. As Lawrence Venuti explains in The Scandals of Translation, "Augustine, bishop of Hippo, feared Jerome's project of translating the Old Testament directly from the Hebrew because it threatened the ideological consistency and institutional stability of the Church" (78). Much later, in the new world, translation had lost none of its political impact. When the first Europeans arrived in what would come to be known as the Americas, translation among the various indigenous peoples had been a well-established fact of social life for thousands of years. According to anthropologist Harold E. Driver, "There were bilingual and even trilingual persons within each social group who could translate when the occasion required" (25). However, the earliest documented cases of translational subversion occurred after the arrival of the European colonial powers. Specifically, in 1535, Jacques Cartier committed a consequential error of over-translation when he referred to all the lands under the sway of Donnacona, chief of Stadacona, as Canada, a French rendering of kanata, the Huron-Iroquoian term for "village" or "settlement," which Cartier first learned from Donnacona's sons Domagaya and Taignoagy (Lamb). Translation scholars 
Pamela Grant and Katy Mezei, drawing on the work of Jean Delisle, furthermore point out that Cartier, through "a violent and coercive act," had taken these two young men back to France in 1534 so that they might later serve as interpreters when he returned to New France. "Thus," Grant and Mezei write, "from early on, translation [in Canada] has borne the stigma of cultural appropriation and colonial exploitation. With both French and English being given official status by the language provisions of the BNA Act of 1867 and by the federal Official Languages Act of 1969, translation has been rooted in political contingency."

This assessment corroborates an earlier appraisal by Pierre Cardinal, who explains that consequent to the rise of French Canadian nationalism in the 1940s and 50s and to the impact of the Quiet Revolution in Quebec in the 1960s, the official "bilingualisation" of Canada became a necessity, and translation a "politically indispensable" activity (142). Writing in 1977, Cardinal shows that the overwhelming balance of (pragmatic) translations at the time were from English to French, due to the dominant position of Anglophones in both government and business. On one level there is, as Cardinal demonstrates, the need for the largely English-speaking Federal administration not only to communicate its policies to the French-speaking minority but also to make that minority feel included in "the life of the country." At the same time, private enterprises run by Anglophones find themselves under rising pressure to translate their publicity into French to increase sales and, more generally, to enhance their corporate image among the French-speaking public. Cardinal concludes that " $\mathrm{t}]$ ranslation has become a buffer institution between our two national groups... The institution of translation thus plays an eminently political-though apparently modest-role in Canadian society... These circumstances cast doubt, at least for the time being, on much of the supposed benefits of translation for the maintenance of our cultural identity and of our rights to equal opportunity"1 (146). So translation is here identified as a means to subvert, even to betray, the democratic national aspirations of the Québecois. If one strictly follows this line of thinking, government and business translators in the 70s - a majority of whom, Cardinal notes, were French-speaking-could be considered "traitors" vis-à-vis their community. In fact, however, the situation is rather more complex, because among other things the increased availability of government documents in French has represented a recognition of Francophone rights and a concession to the social and political clout that French-speaking

${ }^{1}$ My translation. 
Canadians (not only in Quebec) achieved after years of protesting and lobbying in various arenas. But what of literary translation? According to Grant and Mezei, "In the 1960s and 70s, in the face of Quebec's deep discontent and fears about its cultural and linguistic survival, literary translation, especially from French to English, began to flourish." So, while most pragmatic translations during this period were from English into French, most literary translations were in the opposite direction. Various sociological explanations have been proposed to account for this apparent paradox, such as the far lower rate of bilingualism among the English-speaking readers, or the desire among Francophone publishers to focus their efforts on affirming and fostering French, particularly French-Canadian, literature, rather than translations of English writing, in face of the monopolistic tendencies of English. Whatever their merits, however, such hypotheses are by and large premised on a viewpoint outside the lived experience of translators themselves, especially those working from French to English, during those crucial years. What motivated them? And, to return to Jakobson's line of questioning, what messages were they translating? What values were they betraying?

\section{Bearing News from Abroad: 1970 and Beyond}

I think it would be appropriate at this point to adopt an autobiographical approach to such questions. Within the whole momentous period of the Sixties and Seventies, there are good reasons to flag 1970 as a watershed year. For one thing, it was in 1970 that the pre-eminent English translator of Québecois fiction, Sheila Fischman, published her first translation: Roch Carrier's La Guerre, Yes Sir! It was also the year of the first public reading of Michèle Lalonde's now classic poetic denunciation of linguistic colonialism, "Speak White." But 1970 was above all the year of the October Crisis and P.E. Trudeau's invocation of the War Measures Act. This also turned out to be the year when I undertook my first serious attempt at translating a French text into English. The source text begins as follows: "Le Front de libération du Québec n'est pas le messie, ni un Robin des bois des temps modernes. C'est un regroupement de travailleurs québécois qui sont décidés à tout mettre en oeuvre pour que le peuple du Québec prenne définitivement en mains son destin." This, of course, was the FLQ Manifesto. At the time, I was sharing a large flat with six or seven people half of whom were Francophone Québecois, and the other half a variety of English-speakers including another born and bred Montrealer like myself. The flat was located in what is now the trendy Plateau 
Mont-Royal district but which in those days was viewed by most local Anglophones as simply the East, east, that is, of Boulevard Saint-Laurent, the historical boundary between English and French Montreal. My migration from one to the other-which I long regarded as a process of changing countries without changing cities - was in many ways similar to the one mapped out by Sherry Simon in Translating Montreal: Episodes in the Life of a Divided City. In my case, the intellectual baggage that I carried eastward was of the far-left variety. Hence it was not particularly difficult for me to shift from a strong identification with Meursault, the alienated protagonist of Albert Camus' L'Étranger (that I had discovered as a very young undergraduate in a French literature course at McGill University, that bastion of Anglo-bourgeois power) to a passionate identification with the intrepid narrator of Pierre Vallière's Les nègres blancs d'Amérique (my first extracurricular encounter with a book-length French narrative, which I read upon landing in the East). This takes on relevance to the extent that among the elements that compelled me to begin translating the Manifesto within hours of its publication $^{2}$ was its decidedly pro-working-class, anti-capitalist outlook, conveyed through its radical political and economic analysis as well as its brutally iconoclastic language peppered with joual. Indeed, for many of us witnessing the events, the very fact such things were being said and printed in the mainstream media was in itself a revolutionary occurrence on a par with, perhaps to some extent overshadowing, the Manifesto's contents. And likewise, it seemed to me, its translation into English. As a fledgling translator feverishly cutting his teeth on an important, albeit not quite literary, text I was naturally stimulated by both its subject matter and its translational challenges. But I was at least equally excited by the mere idea of smuggling the forbidden text-which through my intervention had now been made to "speak white" - back across the French-English dividing-line. ${ }^{3}$

\footnotetext{
2 The broadcast and publication in the French-language press of the Manifesto were among the conditions set by the FLQ's Liberation Cell for the release of their hostage, British Trade Commissioner Richard Cross. ${ }^{3}$ I was soon to discover that I was far from alone. After dashing off the translation I hurried over to a hushhush meeting at McGill University that had been hastily convened by a Marxist-Feminist sociologist who had migrated north from the USA. I proudly deposited my translation on the professor's desk and saw half a dozen other English versions of the FLQ Manifesto already laid out there. As an epilogue to this anecdote I recently learned from a fellow translator that he had had much the same experience at the same time in Toronto.
} 
Thus, when I entered the history of translation in Canada I was clearly acting as a messenger or, as Weinberger puts it, bearer of "genuine news from abroad" (2), however nearby "abroad" may be. The message, however, cannot be reduced simply to the Manifesto's statement. For, just as the transmission of the FLQ's message via the capitalist-controlled media made visible not just this or that particular power relationship but the very mechanism of mediation, so too the very act of translating that statement into English betrayed not only the status of the English language as a colonial instrument but also shed light on language itself as a medium acting upon our perception of reality.

More recently, more than 35 years after the October Crisis, I had the privilege of translating Nicolas Dickner's novel Nikolski. The position of Nikolski as a milestone in the literary landscape of Quebec has been confirmed by its inclusion in Histoire de la littérature québecoise (published in August 2007), the first major historical survey of Québecois literature to appear in forty years and whose chronology begins with Jacques Cartier's travelogue (alluded to above) and actually closes with Nikolski $(631,649)$. The primary justification for this, in my view, is that this mischievous, multi-layered narrative, composed with the diabolical, mathematical precision of an Escher engraving, frames a new, ground-breaking vision not just of but from Quebec. And, with reference to Roman Jakobson's first question - "translator of what message?" - to relay the scope, detail, and colour of the vision enacted in and by the text was and is the challenge facing us as translators.

By way of circumscribing that vision it may be helpful at the outset to explain that Nikolski traces the intersecting trajectories of three people who, unbeknownst to any of them, have blood ties thanks to Jonas Doucet, a seafarer born in Tête-à-la-Baleine, Quebec, and buried in Nikolski, a hamlet in the Aleutian Islands. Two of the protagonists are Jonas's offsprings by different mothers. The first, an unnamed clerk in a Borgesian second-hand bookstore in Montreal, never knew his father and has only a toy compass forever pointing toward Nikolski to remember him by. The second, Noah Riel, learned to read by studying roadmaps while crisscrossing the Prairies in an old station wagon driven by his Chipewyan mother Sarah. Noah goes off to study archaeology at the Université du Québec à Montréal (UQAM) and eventually lands on Margarita Island, Venezuela. The third protagonist is Joyce Doucet, Jonas's niece and descendant of a long line of Acadian pirates. Joyce runs away from Quebec's 
Lower North Shore to Montreal, where, following in the footsteps of her mother, who vanished just after Joyce's birth, she embarks on a career of computer piracy.

Thus, central to the vision represented in Nikolski are on the one hand the construction and constructedness of identity and genealogy and heritage on the other. Mobile individual space-time coordinates on the one hand and, on the other, interconnectedness, both visible and secret. Furthermore, while the vision is hemispheric and planetary in extent, it moves along the axis of a constantly shifting perspective that zooms into and out from a local, personal position: Canada, Quebec, Montreal, Little Italy, an apartment, a room, a bed, a thought. This mechanism is set in motion already in the opening episode, where the narrator, still half-asleep, is convinced that he is hearing waves breaking on a shore somewhere on Earth and struggles to identify the exact location, only to realize that the sound is coming from a garbage truck in suburban Montreal. The global therefore does not, must not, obviate the specific in Nikolski. The translator (not to mention the publisher) needs to resist the globalizing temptation of allowing Montreal's Petite Italie to become indistinguishable from the Little Italies of Toronto, Boston, or Manchester, for to do so would effect a grave distortion of the organic view of the relationship between the planetary and the particular developed in the novel. Another, more microscopic, case in point: In one scene, the clerk at the loans counter of the UQAM library is reading Gabrielle Roy's La Route d'Altamont $(142,124) .{ }^{4}$ Now, a perfectly good English translation-by Joyce Marshall-of Roy's novel exists under the title The Road Past Altamont. But to have substituted one for the other here ${ }^{5}$ would have severely obscured the specificity of the setting: library clerks in the Université du Québec à Montréal do not as rule read English translations of French- Canadian authors.

It becomes obvious at this point that Jakobson's two questions cannot be answered separately. As evidenced in Nikolski, the vision produced through the narrative gives form to a body of values that at the same time inform that vision. Consequently, to distort the vision inevitably entails a skewing of those values. The potential for such misrepresentations are often found lurking in the tiny folds of a novel's body politic. For instance, the expression "l'An de grâce" (230),

${ }^{4}$ Here and elsewhere, the first page reference is to the French original of Nikolski, the second to the English translation.

${ }^{5}$ As was suggested to me at one point by the publishing house. 
which one would quite naturally be inclined to render in English as "year of our Lord." In the context of Nikolski, however, eschewing the less usual, more dated "year of grace" (206) would implicate the translator in a seemingly minor but in fact egregious violation of both the vision and the values that this novel stages. First, because the Christian allusion would be incongruent with the marked absence in the text of religious references. Second, because this absence bespeaks (in a sense betrays) the secularity that is a crucial legacy of the Quiet Revolution and a hallmark of contemporary Quebec, as well as an essential element of the conceptual environment where Nikolski's characters and narrators live and breathe. Certain translational betrayals, however, are much harder to avoid, as they seem to arise out of the very DNA of prose fiction. In the concluding moments of Nikolski, Noah is in Montreal trying to make a collect call to Venezuela. An international operator answers:

"Hi-bonsoir-comment-puis-je-vous-aider-how-can-I-help-you?"

For a few seconds Noah is thrown off balance. The accent seems to be neither Québecois nor American nor Latin American, but a sort of amalgam originating in every place and no place at the same time, as if the voice did not really belong to a human being but to a spurt of DNA designed to meet a specific need and then injected into the circuits of the telephone system. An entity with no accent, no nationality and no trade-union demands $(307-308,274)$.

This passage brings into stark relief one of the areas where the translator is most vulnerable to treason: dialogue. Fictional narrative's overall effect vitally depends on characterization, whose success in turn depends so much on the convincing performance of dialogue, yet the translator is generally expected to make the characters express themselves with native fluency in a language which is not their own. As a result, the Québecois and French-Canadian characters in Nikolski are in danger of being not just left with "no accent, no nationality" but effectively absorbed into the vast international waters of English. This may be one area where the "foreignizing" strategy, proposed most notably by Lawrence Venuti, may open up interesting alternative avenues and prospects.

One quite elaborate example of the application of such a strategy is provided in Faulkner, une expérience de retraduction, edited by Annick Chapdelaine and Gillian Lane-Mercier, which describes the experimental re-translation of Faulkner's "The Hamlet" by the McGill University-based Groupe de recherche en traductologie (GRETI). The guiding principle of the project was to recreate "in a decentred way the narrative and dialogic components, which in our view had 
been domesticated in the [continental] French version" 6 (21). The decentring principle is explained in terms of a "non-annexationist" approach opposed to the naturalisation of Faulkner's text within the receiving culture. A basic concern, therefore, was to strike a satisfactory balance between the "foreign" and the "strange" in the text (18). Concretely, the methods used by GRETI to achieve its objectives include solutions familiar to professional translators, such as the nontranslation of geographic and social markers (e.g. place names and the names and titles of characters), but the crucial innovation was the use, specifically in dialogue, of Québecois vernacular to achieve a "sociolectal charge" equivalent to that of the Southern vernacular of the original. The aim, however, was not "to translate Faulkner for Quebec, but rather to translate him, via Quebec, for the Francophone community - more precisely for a model Francophone reader" (21). Indeed, the translators were fully aware of the political, even subversive, implications of their project, which in their view involved "a quest for freedom," "a desire to break with [continental] French tradition," and the "need to learn to use Québecois French as a language of translation" (21).

So, on the level of general principles, there is a clear convergence of between, on the one hand, GRETI's rejection of "annexationist" translation that domesticates and naturalizes the foreign text to facilitate its assimilation into the domestic literary market and, on the other, the resistance to globalizing, absorptive translation, that is, the strategy I argue for above. At the same time, however, the core social-linguistic considerations of the Faulkner project are essentially bound up with the cultural and political power relationships within la Francophonie, which give rise to challenges obviously very different from, in some ways opposite to, those attending the translation into English of a contemporary Québecois novel like Nikolski.7 Furthermore, and perhaps more fundamentally, the translators involved in the GRETI project were faced with the kinds of ethical dilemmas that all translators, wittingly or not, must confront, for such issues reside in the translational gesture itself. They wondered, for example, "whether in superimposing the two worlds, Quebec and the Deep South, [they] did not run the risk of producing an annexationist translation in direct contradiction with our aims"; they fretted over the dangers of "excessive vernacularisation"; they were

\footnotetext{
${ }^{6}$ Translator: René Hilleret. Note that this and other translations of passages from Faulkner, une expérience de retraduction are my own.

${ }^{7}$ It is worth pointing out as well that the GRETI project was carried out in "privileged conditions,.. unhampered by the usual commercial and literary imperatives" (13), in other words, conditions far removed from the objective material circumstances in which the vast majority of translators exercise their profession.
} 
torn between the "jubilation" that comes from engaging in such a bold undertaking and a "persistent anxiety over the possible reactions of readers (particularly in France)" (21).

All this points to the conclusion that whatever devices translators may deploy, we cannot ultimately outmanoeuvre the intrinsic operations of translation as a medium. We may enjoy some freedom in choosing to transport this or that message across the language barrier because of its political import or power to subvert, the fact remains, to quote Robert Eaglestone's paraphrasing of Paul de Man, that "what I translate is upset by the way I translate" (137) because "[W]hat I mean is upset by the way I mean" (135). What the translator betrays, then, has much to do with the "politics" of the translated message and the political, geo-political stakes of the act of translation, but ultimately she also betrays her own status and the status of translation as medium, and by inference the unmentionable fact that all human experience is "always already" mediated, language being the primal, primary medium. One is reminded of Jim Carrey in Peter Weir's film The Truman Show, literally poking his finger through the envelope of "reality." This, fundamentally, is why in the publishing world translations are required to be utterly legible yet perfectly transparent, why translators may be read but never seen, much less heard. Their visibility would be a huge embarrassment, a shocking betrayal. 
TranscUlturAl, vol.1, 2(2009), 35-46

http://ejournals.library.ualberta.ca/index.php/TC

\section{REFERENCES}

Biron, Michel, François Dumont, Elisabeth Nardout-Lafarge. Histoire de la littérature québecoise. Montreal: Boréal, 2007.

Camus, Albert. L'Étranger. Paris: Gallimard, 1942.

Cardinal, Pierre. "Regard critique sur la traduction au Canada." Meta 23.2 (1978):

141-147. 11 November 2008. http://id.erudit.org/iderudit/002204ar

Chapdelaine, Annick and Gillian Lane-Mercier (Eds). Faulkner, une expérience de retraduction. Montréal: Les Presses de la Université de Montréal, 2001. 15

June 2009. http://site.ebrary.com/lib/usherbrooke/Doc?id=10176821\&ppg=1

Dickner, Nicolas. Nikolski. Québec: Alto, 2005.

---. Nikolski. Trans. Lazer Lederhendler. Toronto: Knopf Canada, 2008.

Driver, Harold E. Indians of North America, Second Edition, Revised. Chicago: The

University of Chicago Press, 1969.

Eaglestone, Robert. "Levinas, Translation, and Ethics." Nation, Language, and the

Ethics of Translation. Eds. Sandra Bermann and Michael Wood. Princeton,

NJ: Princeton University Press, 2005. 127-138.

Grant, Pamela, and Kathy Mezei. "Background to Literary Translation in

Canada." 28 Aug. 2008.

http://compcanlit.usherbrooke.ca/about translation.html

Jakobson, Roman. “On Linguistic Aspects of Translation." Language in Literature.

Cambridge, Mass.: Belknap-Harvard University Press, 1987.

Lamb, W. Kaye. “Canada.” 25 Sept. 2008.

http://www.thecanadianencyclopedia.com

“Manifeste du Front de Libération du Québec." October 1970. 18 Sept. 2008.

http://pages.infinit.net/histoire/manifst flq.html

Paz, Octavio. "Translation: Literature and Letters." Theories of Translation: An

Anthology of Essays from Dryden to Derrida. Eds. Rainer Schulte and John

Biguenet. Chicago: The University of Chicago Press, 1992. 152-162.

Simon, Sherry. Translating Montreal: Episodes in the Life of a Divided City. Montreal: McGill-Queen's UP, 2006.

The Truman Show. Dir. Peter Weir. Perf. Jim Carrey, Laura Linney. Paramount

Pictures, 1998.

Vallières, Pierre. Nègres blancs d'Amérique. Montreal: Parti pris, 1968.

Venuti, Lawrence. The Scandals of Translation: Towards an Ethics of Difference.

London: Routledge, 1998.

Weinberger, Eliot. "Anonymous Sources: A Talk On Translators \& Translation." 
TranscUlturAl, vol.1, 2(2009), 35-46

http://ejournals.library.ualberta.ca/index.php/TC

Fascicle Issue 01. Summer 2005. 22 Sept. 2008

http://www.fascicle.com/issue01/Poets/weinberger1.htm

(C) Copyrights TranscllturAl \& Author (2009) 